\title{
Congenital Chylothorax of the Newborn: A Systematic Analysis of Published Cases between 1990 and 2018
}

\author{
Bernhard Resch ${ }^{a} b \quad$ Gülsen Sever Yildiz ${ }^{a} \quad$ Friedrich Reiterer ${ }^{b}$ \\ ${ }^{a}$ Research Unit for Neonatal Infectious Diseases and Epidemiology, Medical University of Graz, Graz, Austria; \\ ${ }^{b}$ Division of Neonatology, Department of Pediatrics and Adolescent Medicine, Medical University of Graz, Graz, \\ Austria
}

\section{Keywords \\ Congenital chylothorax - Associated anomalies - Mortality · \\ Octreotide · OK-432 - Pleurodesis · Povidone-iodine}

\begin{abstract}
Background: Congenital chylothorax (CCT) of the newborn is a rare entity but the most common cause of pleural effusion in this age-group. We aimed to find the optimal treatment strategy. Material and Methods: A PubMed search was performed according to the PRISMA criteria. All cases were analyzed according to prenatal, perinatal, and postnatal treatment modalities and follow-ups. Results: We identified 753 cases from 157 studies published between 1990 and 2018. The all-cause mortality rate was $28 \%$. Prematurity was present in $71 \%$, male gender dominated $57 \%$, mean gestational age was 34 weeks, and birth weight was 2,654 g. Seventynine percent of newborns had bilateral CCT, the most common associated congenital anomalies with CCT were pulmonary lymphangiectasia and pulmonary hypoplasia, and the most common chromosomal aberrations were Down, Noonan, and Turner syndromes, respectively. Mechanical ventilation was reported in 381 cases for mean 17 (range 1-120) days; pleural punctuations and drainages were performed in $32 \%$ and $64 \%$, respectively. Forty-four percent received total parenteral nutrition (TPN) for mean 21 days, 46\% medium-
\end{abstract}

chain triglyceride (MCT) diet for mean 37 days, 20\% octreotide, and 3\% somatostatin; chemical pleurodesis was performed in 116 cases, and surgery was reported in 48 cases with a success rate of $69 \%$. In 462 cases (68\%), complete restitution was reported; in 34 of 44 cases (77\%), intrauterine intervention was carried out. Conclusion: Respiratory support, pleural drainages, TPN, and MCT diet as octreotide remain to be the cornerstones of CCT management. Pleurodesis with OK-432 done prenatally and povidone-iodine postnatally might be discussed for use in life-threatening CCT.

๑) 2021 The Author(s).

Published by S. Karger AG, Basel

\section{Introduction}

Congenital chylothorax (CCT) of the newborn is a rare disease with high associated morbidity and mortality. CCT is defined as an effusion of lymph in the pleural cavity [1]. In contrast to the congenital idiopathic or spontaneous form of chylothorax, there exists a traumatic chylothorax, most common as a complication of surgery with iatrogenic rupture of the ductus thoracicus (surgery of congenital heart disease or atresia of the esophagus), and a symptomatic one as a result of a venous congestion (tumors, thromboses, cancers, etc.). karger@karger.com www.karger.com/res

Karger $\stackrel{\text { ' }}{5}$

GOPEN ACCESS
(C) 2021 The Author(s)

Published by S. Karger AG, Basel

This is an Open Access article licensed under the Creative Commons Attribution-NonCommercial-4.0 International License (CC BY-NC) (http://www.karger.com/Services/OpenAccessLicense), applicable to the online version of the article only. Usage and distribution for commercial purposes requires written permission.
Correspondence to:

Bernhard Resch, bernhard.resch@medunigraz.at 


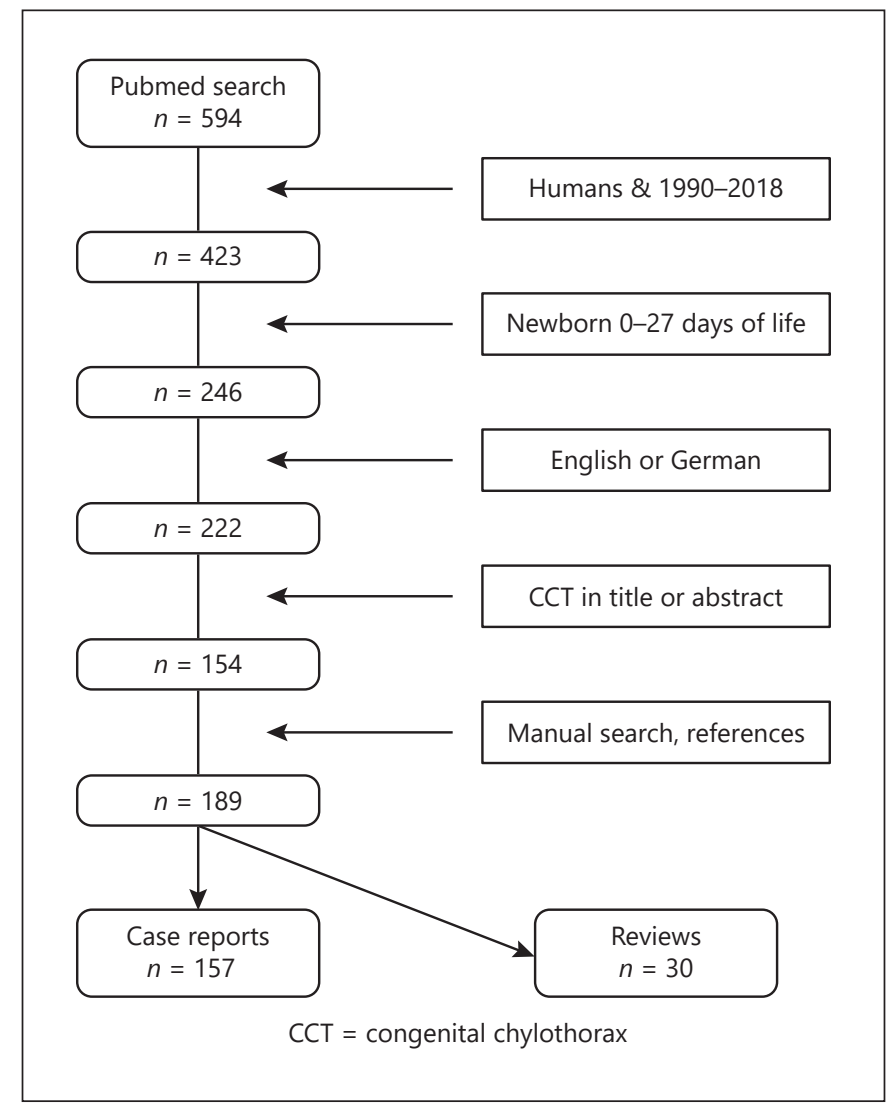

Fig. 1. Literature review identifying 157 case reports or case series on CCT between 1990 and 2018 according to the PRISMA criteria. CCT, congenital chylothorax.

A lot of reviews [1-30] and case reports or case series [31-187] of CCT have been published during the last 3 decades (1990-2018). The first report of CCT was published in 1917 [188], but some researchers were not sure about its congenital etiology, and thus, Stewart and Linner (1926) have often been cited as the first authors who described CCT [189]. In 1928, the first report of prenatal diagnosis was published [190]. CCT was reported to occur in one per 7,300 to 10,000 live births $[26,106,137]$. Estimations of the prevalence of CCT range between $1: 10,000$ [30] and 1:24,000 [173]. In severe cases with large amounts of pleural effusions, lung hypoplasia might result and consequently heart failure due to compromised vascular flow and hydrops fetalis. As a result, lymphocytes, antibodies, complement, and coagulation factors and also nutritional and fluid content and immune globulins might get lost in the pleural cavity or via drainages. These chylous fluid losses again might lead to malnutrition and dehydration and to increased risks of infec- tious complications or bleeding episodes [30]. Additional risks included concomitant anomalies or genetic disorders that might negatively influence the prognosis of CCT. Despite modern neonatal intensive care, mortality rates reported ranged between 30 and $70 \%$ according to the literature [191]. We aimed to depicture the whole spectrum of disease by a review of cases and case series from the literature between 1990 and 2018 and to systematically analyze them with a focus on treatment strategies.

\section{Material and Methods}

We performed a systematic review of the literature using "Pubmed" and searching the medical subject heading "congenital chylothorax" according to the PRISMA criteria. Included were all newborn infants younger than 29 days of life published between 1990 and 2018. The literature search and case analysis was done between August 2018 and October 2019. Within the study period, we found 467 studies; further, we used "humans" and "newborns 0-27 days" and included only German or English written articles. Thus, we reduced the number of studies to 222 . These publications had to have the wording "congenital chylothorax" or "congenital pleural effusion" in the title or abstract of the study. A manual search through the references revealed the final number of 157 studies reporting cases or case series with CCT (see Fig. 1).

Inclusion criteria were more than $70 \%$ lymphocytes in the pleural fluid or presence of chylomicrons or high triglyceride levels $(>110 \mathrm{mg} / \mathrm{mL})$. Exclusion criteria were missing inclusion criteria and secondary CCT due to (cardiac) surgery or iatrogenic forms of CCT.

Perinatal data included gender, birth weight, gestational age in weeks, cesarean section or vaginal birth, presence of intrauterine drainages of the pleura, other fetal interventions, preterm birth, surgery of any kind, time of CCT resolved, any nosocomial infection, presence of fetal hydrops, associated malformations, and chromosomal anomalies. Further, we collected the age and duration of each of the following procedures: pleural drainages, pleural punctuation, mechanical ventilation (MV) - either invasive or noninvasive (continuous positive airway pressure and high flow nasal cannula), total parenteral nutrition (TPN), medium-chain triglyceride (MCT) diet, somatostatin or octreotide treatment, surgery, chemical pleurodesis, and finally length of hospitalization, survival, discharge healthy, and death. In order to present the data in a reader-friendly format, we did not list all the references associated with each finding (see online supplementary data, available at www.karger.com/doi/10.1159/000518217).

\section{Results}

During the study period, 760 cases with CCT were identified for further analysis from 157 publications [31187]. The exact inclusion criteria were fulfilled in 753 cases that comprised the study population. Seventy-one per- 
Table 1. Prenatal and perinatal data of 753 cases with CCT extracted from the literature from 1990 to 2018

\begin{tabular}{lcc}
\hline Parameter & Patients with data & Results \\
\hline Total number of cases & & $\mathbf{7 5 3 ( \mathbf { 1 0 0 } )}$ \\
Prenatal diagnosis & $\mathbf{5 1 2 ( \mathbf { 6 8 } )}$ \\
Age of prenatal diagnosis, weeks & 324 of 512 & $28.8(16-38)$ \\
Prenatal intervention & & $316(62)$ \\
Age of prenatal intervention, weeks & 181 of 316 & $29.7(17-38)$ \\
Intrauterine death/termination of pregnancy/perinatal death & & $42 / 13 / 17$ \\
Polyhydramnion & & $96(13)$ \\
Hydrops fetalis (nonimmunologic) & & $288(38)$ \\
Survivors with follow-up & & $\mathbf{6 8 1}(\mathbf{9 0})$ \\
Cesarean section & 290 of 681 & $159(55)$ \\
Prematurity (<37 weeks gestation') & 472 & $337(71)$ \\
Gestational age, weeks & 565 of 681 & $34.3(26-41)$ \\
Birth weight, grams & 469 of 681 & $2,654(467-4,715)$ \\
Male gender & 425 & $243(57)$ \\
Pleural fluid with lymphocytes $>70 \%$ & & $579(77)$ \\
Bilateral pleural effusions & 460 & $362(79)$ \\
\hline
\end{tabular}

Numbers are given as $n(\%)$ or mean (range), CCT, congenital chylothorax.

cent of infants were preterm born; 10 studies did not report data on gestational age $[31,33,39,74,78,85,121$, $127,138,146]$. Intrauterine death occurred in 42 cases; termination of pregnancy occurred in 13 reports.

Thus, 698 were born alive, and 17 cases died during birth or immediately after birth. Perinatal data of the total study population and the 681 newborns with follow-up are shown in Table 1. Yang et al. [155] solely reported a range of 16-29 weeks of gestational age and therefore not included. Same was done with the study of Shih et al. [150] regarding birth weights (range 780-3,110 g in 4 cases).

\section{Diagnosis}

Diagnosis of CCT confirmed by lymphocyte rates of $>70 \%$ was found in $77 \%$ of cases. Two studies reported "a lot of" lymphocytes [37, 41], and in 15 cases $(2 \%)$, authors solely reported that lymphocytes were dominant or predominant $[38,39,142]$. In 7 cases $(1 \%)$, lymphocytes were below $70 \%[48,112]$. In the majority of cases, there are no specific lym phatic system studies necessary to identify the exact pathology [30]. Additionally, expertise on lymphatic studies is not universally available [30] and has been published by only one working group $[91,130]$.

\section{Prenatal Treatment}

Prenatal interventions were reported in 316 of 512 (62\%) prenatally diagnosed cases. One hundred eighty one cases had data on gestational age. Information re- garding prenatal punctuation was given in $128(40 \%)$, thoraco-amniotic shunting in 137 (43\%), and both in 17 cases $(5 \%)$. Some of the pleural punctuations were done prior to delivery to avoid perinatal asphyxia. Mussat et al. [48] reported on 20 cases with intrauterine shunt implantation and 4 cases with intrauterine punctuation; thereafter, 16 cases reconvert with improvements regarding the course of disease and its treatment. Picone et al. [89] reported on 44 intrauterine shunted cases (thoraco-amnial) with recurrent punctuations until birth. Chen et al. [126] published 17 cases with intrauterine punctuations of pleural effusions, and some of these punctuations immediately before birth were found to ameliorate postpartal adaption of the newborn [60]. Mussat et al. [48] reported clinical improvement in $2 / 3$ of the procedures (shunting in 20 and punctuation in 4 cases). Gonen et al. [60] reported on recurrent prenatal punctuations in 4 cases including one immediately before birth. Two centers demonstrated a lot of experience with prenatal shunting (44 and 17 cases, respectively) $[89,128]$. Rates of fetal interventions including intrauterine punctuation and thoraco-amniotic shunting are shown in Table 1.

A total of 87 cases were treated with fetal intrapleural instillation of OK-432 (Picibanil, a sclerosant and immunostimulant). Tanemura et al. [73] and Okawa et al. [74] first published the method in 2001. Yang et al. [155] reported on a cohort of 45 fetuses - the largest cohort - having been treated with OK-432. Thirty-one fetuses survived the OK-432 procedure, having either a complete
86

Respiration 2022;101:84-96 DOI: $10.1159 / 000518217$
Resch/Sever Yildiz/Reiterer 
Table 2. Associated anomalies and chronic sequelae* found in 216 of 753 cases with CCT of the newborn from the literature between 1990 and 2018

\begin{tabular}{|c|c|c|c|}
\hline \multicolumn{2}{|l|}{ Lung } & \multicolumn{2}{|l|}{ Lymphatics (outside the lungs) } \\
\hline Congenital pulmonary lymphangiectasia & 47 & Lymphatic dysplasia/malformation & 15 \\
\hline Pulmonary hypoplasia & 43 & Lymphangiectasia generalisata & 3 \\
\hline $\mathrm{BPD}^{*}$ & 5 & Anomaly of the thoracic duct & 2 \\
\hline Sequestration of the lung & 4 & Primary hereditary lymphedema & 1 \\
\hline Subglottic stenosis & 2 & Lymphangiomatosis & 1 \\
\hline Right lung 2 lobes & 1 & Lymphodysplastic syndrome & 1 \\
\hline Cystic adenomatous malformation & 1 & Sum & 23 \\
\hline Hemorrhagic lung edema & 1 & Other anomalies & \\
\hline Laryngomalacia & 1 & Hydrocele testis & 4 \\
\hline Congenital diaphragmatic hernia & 1 & Hypertelorism & 3 \\
\hline Sum & 106 & Myelodysplastic-monocytic leukemia & 2 \\
\hline Heart and vessels & & Congenital hypothyreosis & 2 \\
\hline Ventricular septal defect & 7 & Cleft lip and palate & 2 \\
\hline Atrial septal defect & 6 & Hygroma colli & 2 \\
\hline Atrioventricular channel defect & 6 & Malformations, multiple & 1 \\
\hline Heart defect (no details) & 6 & Hydronephrosis & 1 \\
\hline Persistent ductus arteriosus Botalli & 4 & Horseshoe kidney & 1 \\
\hline Persistent foramen ovale & 3 & Congenial lipodystrophia & 1 \\
\hline Hypoplastic vena cava superior & 3 & Kryptorchism & 1 \\
\hline Tetralogy of Fallot & 3 & Hypospadia & 1 \\
\hline Arteriovenous malformation & 2 & Gastroschisis & 1 \\
\hline Aortic isthmus stenosis & 2 & Mediastinal neuroblastoma & 1 \\
\hline Pulmonary artery stenosis & 2 & Polydactylia & 1 \\
\hline Hypertrophic cardiomyopathy & 2 & Omphalocele & 1 \\
\hline Hypoplastic left heart syndrome & 1 & Cervical teratoma & 1 \\
\hline Aplasia of pulmonary valves & 1 & Pyloric stenosis & 1 \\
\hline Pericardial teratoma & 1 & Sum & 27 \\
\hline Missing left subclavian artery & 1 & Brain & \\
\hline Sinus venosus defect & 1 & Microcephaly & 2 \\
\hline Missing vena azygos & 1 & Encephalopathy & 1 \\
\hline Single umbilical artery & 1 & Agenesis of the corpus callosum & 1 \\
\hline Ebstein anomaly & 1 & Intraventricular hemorrhage & 1 \\
\hline Venous malformation & 1 & Intracranial hemorrhage & 1 \\
\hline \multirow{2}{*}{ Sum } & 53 & Ventriculomegaly & 1 \\
\hline & & Sum & 7 \\
\hline
\end{tabular}

BPD, bronchopulmonary dysplasia; CCT, congenital chylothorax. * Preterm infants with CCT developing chronic lung diseases of prematurity (BPD).

$(n=8)$ or a partial $(n=23)$ response, and were followedup every 2 weeks until delivery. Sixteen of these (51.6\%) survived beyond 1 month of age, while 15 (48.4\%) resulted in neonatal deaths [155]. In 13 cases, time point of intervention was documented being mean 21.5 (range 1633) weeks. In 54 cases, no details were provided, for example, Lee et al. [180] who did not describe their method but reported on 3 intervention modalities - pleurodesis, thoracocentesis, or thoraco-amniotic shunting. Parra et al. [80] uniquely instilled maternal blood into the fetal intrapleural cavity in 2003.

Treatment of Congenital Chylothorax

\section{Anomalies and Genetics}

In 217 cases (29\%), associated anomalies had been reported (see Table 2). The majority were pulmonary findings and anomalies associated with the lymphatic system - 47 cases with congenital pulmonary lymphangiectasia and 43 cases with pulmonary hypoplasia and 21 malformations of the lymphatic system, in total 111 (51\%). Congenital heart disease was observed in 52 cases including malformations of the arteriovenous system $(24 \%)$. 
Table 3. Chromosomal findings in 117 of 753 cases with CCT of the newborn between 1990 and 2018

\begin{tabular}{lc}
\hline Genetic disorder & $N(\%)$ \\
\hline Down syndrome & $48(41.1)$ \\
Noonan syndrome & $26(22.2)$ \\
Turner syndrome & $10(8.6)$ \\
Anomalies regarding chromosomes, 13/14 & $6(5.1)$ \\
C syndrome = Opitz syndrome & $3(2.6)$ \\
Edward syndrome & $2(1.7)$ \\
Hennekam syndrome & $2(1.7)$ \\
Klinefelter syndrome & $2(1.7)$ \\
Anomalies regarding chromosome 2 & $2(1.7)$ \\
X-linked myotubular myopathy & $2(1.7)$ \\
Anomalies regarding chromosome 7 & $2(1.7)$ \\
Ehlers-Danlos syndrome & $1(0.9)$ \\
Anomalies regarding chromosome 9 & $1(0.9)$ \\
Alagille syndrome & $1(0.9)$ \\
Schienzel-Giedion syndrome & $1(0.9)$ \\
Mitochondrial myopathy & $1(0.9)$ \\
Kabuki syndrome & $1(0.9)$ \\
Trisomy X (mosaik 47XXX/46XX) & $1(0.9)$ \\
Gorlin syndrome & $1(0.9)$ \\
XYY syndrome & $1(0.9)$ \\
Jacobsen syndrome & $1(0.9)$ \\
CDG syndrome (congenital disorders of & \\
N-glycosylation) & $1(0.9)$ \\
Cornelia de Lange syndrome & $1(0.9)$ \\
Sum & $117(\mathbf{1 0 0})$ \\
\hline
\end{tabular}

CCT, congenital chylothorax.

Chromosomal aberrations were found in 118 cases (18\%). Disorders are listed in Table 3. Down, Noonan, and Turner syndromes were the most common diagnosed entities (48, 26, and 10 cases, respectively).

\section{Postnatal Course of Disease}

Pleural punctuation of CCT was reported in 218 of 681 newborns who had survived and been followed postnatally (32\%); pleural drainage was inserted in 438 cases (64\%). Indications were desaturation below $90 \%$ and increased work of breathing. Durations of pleural drainages were documented in 225 newborns with a mean of 20 (range 1-150) days. Zenker et al. [54] reported only a range of 10-44 days from a series of 17 cases. Fernandez Alvarez et al. [62] reported 6 cases with pleural drainages; they did not document the duration but the number of drainages per newborn, with a range of 1-15.

MV was reported in 381 cases (56\%). Of 213 ventilated cases with data on duration of MV, a mean of 17 (range 1-120) days was documented. Seventy newborns (10\%) developed pneumothorax. In 78 newborns (11\%), a diagnosis of sepsis was documented. A case of extremely long duration of MV reported by Ergaz et al. [137] with 885 days was not included in the final analysis as was not a case series by Zenker et al. [54] who reported only a range of 9-47 days.

TPN was reported in 296 cases (44\%), and the duration (details from 113 newborns) was documented with mean 21 (range 2-81) days. MCT diet was given in 315 newborns (46\%), and only 19 cases provided data on the duration of MCT diet (mean 37, range 5-50 days). In 13 cases, initiation of MCT diet was provided at mean 21 days (7-68). In 96 cases a prenatal MCT diet of the mother was reported.

Somatostatin and octreotide (somatostatin analog) for the treatment of CCT were first described by Goto et al. in 2003 [86]. Cleveland et al. [142] reported the largest case series of 13 newborns having received both drugs. Data on octreotide treatment were documented in 138 cases with a mean duration of 22 days (range 3-151 days from 76 newborns). Sixty-two case reports did not provide information on duration of octreotide treatment; 66 newborns received octreotide intravenously and 6 newborns subcutaneously. Octreotide treatment was started between days 2 and 109. Initial intravenous dosage varied between 3 and $4 \mu \mathrm{g} / \mathrm{kg} / \mathrm{h}$ and maximum dosage between 6 and $12 \mu \mathrm{g} / \mathrm{kg} / \mathrm{h}$. Subcutaneous injection was given at dosages ranging between 1 and $40 \mu \mathrm{g} / \mathrm{kg} /$ day initially and maximum dosages between 24 and $70 \mu \mathrm{g} / \mathrm{kg} /$ day. In 30 cases, therapy with octreotide failed, resulting in subsequent surgery. Coulter et al. [93] reported on a case with failure of surgical ligation of the ductus thoracicus and subsequent successful octreotide therapy.

Somatostatin treatment was described in 22 cases (3\%). Duration of treatment was provided in 3 cases (10, 18 , and 23 days, respectively, with a mean of 17 days). In a case series of Cannizarro et al. [114], 3 newborns with intravenous somatostatin were reported. Somatostatin was started with $3.5 \mu \mathrm{g} / \mathrm{kg} / \mathrm{h}$ and gradually increased to $12 \mu \mathrm{g} / \mathrm{kg} / \mathrm{h}$.

Forty-eight newborns (7\%) received prophylactic and therapeutic antibiotics, 40 received steroids, and 56 surfactant. Immune globulins were given in 29 case reports (4\%). Twenty-five case reports casually mentioned this information in contrast to one report with weekly immune globulin treatment and another with treatment twice a week [70, 181]. Bulbul et al. [138] described a case with postpartal immune globulin therapy at a dosage of 1 $\mathrm{mg} / \mathrm{kg}$, and Gupta et al. [167] gave immune globulins every $24 \mathrm{~h}$ with a dosage of $2 \mathrm{~g} / \mathrm{kg}$. 
Table 4. Chemical pleurodesis and surgical procedures in CCT of the newborn from 157 out of 753 cases from the literature between 1990 and 2018

\begin{tabular}{llc}
\hline Procedure & Agents used for pleurodesis & Interventions $(n)$ \\
\hline Chemical pleurodesis & & $\mathbf{1 1 6}$ \\
$\quad$ Intrauterine + postnatal & OK-432 & $87+2$ \\
Postnatal & Povidone-iodine & 12 \\
Postnatal & Minocyclin & 5 \\
Postnatal & Dextrose & 2 \\
Postnatal & Oxytetracycline & 2 \\
Postnatal & Bleomycin & 1 \\
Postnatal & Fibrin glue & 1 \\
Postnatal & Pleurodesis (unclear) & 2 \\
Intrauterine & Maternal blood (in utero) & 1 \\
Postnatal & Autologous blood & 1 \\
Surgical pleurodesis & & $\mathbf{2 3}$ \\
Ligation of the thoracic duct & & $\mathbf{1 5}$ \\
Pleuroperitoneal shunt & & $\mathbf{8}$ \\
Partial surgical pleurodesis & & $\mathbf{2}$ \\
\hline
\end{tabular}

Multiple interventions in one case possible. CCT, congenital chylothorax.

\section{Surgery and Chemical Pleurodesis}

In 157 case reports (23\%), surgery including chemical pleurodesis was the final treatment to cure CCT. Time of surgery was at a mean of 39 days (range 11-150 days; data from 41 cases). An extremely late surgical intervention was reported by Bellini et al. [159] at the age of 2 years (successful pleurodesis). In Table 4, the different interventions are described that have been successful in 105 of 150 cases $(67 \%)$.

Chemical pleurodesis with OK-432 was done in $62 \%$ of newborns, and prenatally used in 87 cases and in one newborn with maternal blood [80]. Successful interventions were reported in 71 postnatal and 44 prenatal cases. Successful surgical pleurodesis was reported in 20 of 25 cases $(80 \%)$, ligation of the ductus thoracicus in 10 out of 15 cases $(67 \%)$, and pleuroperitoneal shunting in 4 of 8 cases $(50 \%)$.

\section{Mortality}

Death occurred in 138 newborns who were primarily born alive with data from 77 infants regarding time of death (mean 25, range 1-202 days). Twelve newborns died on the first day of life and 6 within $48 \mathrm{~h}$. Lee et al. [180] published 13 cases who died between day 1 and 28 [133]. Thus, all-cause mortality including termination of pregnancy was $27.9 \%$. Causes of deaths (89 cases with data) included respiratory insufficiency $(n=26)$ and pulmonary hypoplasia $(n=24)$, infectious complications and sepsis $(n=15)$, renal failure $(n=6)$, multi-organ failure $(n=3)$, lymphangiectasia $(n=3)$, pulmonary obstructive disease $(n=3)$, aspiration $(n=2)$, and rare causes includ- ing lymphedema, Opitz syndrome, interstitial fibrosis, intra-alveolar and interstitial hemorrhage, pulmonary hypertension, pneumopericardium, and Ebstein anomaly.

\section{Regression of CCT and Hospitalization}

In 462 cases (68\%), complete restitution was reported; in 34 of 44 cases, following intrauterine intervention; and in 81 cases, the outcome was unknown. Time of complete regression of CCT was at a mean of 28 (range 1-148) days. In those cases treated prenatally (8 cases), pleural effusions were reported to have resolved at 24 weeks of gestation (range 19-26). Chen et al. [126] reported 12 of 17 cases treated successfully intrauterine. Bellini et al. [159] reported 26 of 33 cases having had survived and been discharged with MCT diet. Only rare and mild cases of CCT are managed by a wait-and-see strategy $[5,22,26,37]$. Length of hospitalization was documented in 223 newborns with a mean of 41 (range 4-386) days.

\section{Follow-Up}

The mean duration of follow-up of 133 newborns (29\%) was 14.7 (range 1-144) months. The longest follow-up was reported by Resch et al. [158] including 6 cases followed up to the age of 12 years. Recurrence of pleural effusions has not been reported [34, 37, 48, 158]. Longterm observations revealed 2 cases having interstitial infiltrations, one asthma bronchiale, one pulmonary obstructive disease, and finally one having pleural fibrosis. Dutheil et al. [58] described one case having prolonged pleural fluids lasting over months that resolved at the age 
Table 5. Summary of postnatal treatment, complications, and outcomes of 681 cases with CCT published between 1990 and 2018

\begin{tabular}{|c|c|}
\hline Treatment modalities & $\begin{array}{l}N(\%) \text { or } \\
\text { mean (range) }\end{array}$ \\
\hline MV & $381(56)$ \\
\hline Duration of ventilatory support, days ${ }^{1}$ & $17(1-120)$ \\
\hline Pleural punctuation & $218(32)$ \\
\hline Pleural drainage & $438(64)$ \\
\hline Duration of drainages, days ${ }^{2}$ & $20(1-150)$ \\
\hline TPN & $296(44)$ \\
\hline Duration of TPN (days) ${ }^{3}$ & $21(2-81)$ \\
\hline MCT diet & $315(46)$ \\
\hline Duration of MCT diet (days) ${ }^{4}$ & $37(5-50)$ \\
\hline Octreotide & $138(20)$ \\
\hline Duration of octreotide treatment (days) ${ }^{5}$ & $22(3-151)$ \\
\hline Somatostatin & $22(3)$ \\
\hline Duration of somatostatin treatment (days) ${ }^{6}$ & $17(8-23)$ \\
\hline Antibiotics & $48(7)$ \\
\hline Surfactant & $56(8)$ \\
\hline Steroids & $40(6)$ \\
\hline Immune globulins & $29(4)$ \\
\hline \multicolumn{2}{|l|}{ Surgical interventions including chemical } \\
\hline Time at intervention (day of life) ${ }^{7}$ & $39(11-150)$ \\
\hline Successful intervention & $105(67)$ \\
\hline \multicolumn{2}{|c|}{ Complications/associated anomalies/genetic disorder } \\
\hline Pneumothorax & $70(10.3)$ \\
\hline Sepsis & $78(11)$ \\
\hline Associated anomalies & $217(29)$ \\
\hline Chromosomal aberrations, genetic disorders & $118(16)$ \\
\hline \multicolumn{2}{|l|}{ Outcomes } \\
\hline Discharged healthy & $462(68)$ \\
\hline Discharged with unknown health status & $81(12)$ \\
\hline Duration of treatment ${ }^{8}$ & $28(1-148)$ \\
\hline Deaths & $138(20)$ \\
\hline Time at death (day of life $)^{9}$ & $25(1-202)$ \\
\hline Duration of hospitalization, days ${ }^{10}$ & $41(4-386)$ \\
\hline Follow-up of $133 / 543$ cases (25\%), months & $14.7(1-144)$ \\
\hline
\end{tabular}

CCT, congenital chylothorax; TPN, total parenteral nutrition; MV, mechanical ventilation; MCT, medium chain triglyceride. ${ }^{1}$ Data from 213 cases. ${ }^{2}$ Data from 225 cases. ${ }^{3}$ Data from 113 cases.

${ }^{4}$ Data from 19 cases. ${ }^{5}$ Data from 76 cases. ${ }^{6}$ Data from 3 cases.

${ }^{7}$ Data from 41 cases. ${ }^{8}$ Data from 79 cases. ${ }^{9}$ Data from 77 cases. ${ }^{10}$ Data from 223 cases.

of 1 year. Al-Tawil et al. [68] reported 17 cases being healthy between the age of 6 months and 7 years; one case with Down syndrome died at the age of 7 months due to congenital heart disease. One case with eosinophilic pulmonary vasculitis was discharged at day 104 of life and reported to be healthy at the age of 2 years [79]. A summary of the postnatal course of CCT from 681 live born cases is shown in Table 5.

\section{Treatment Algorithm}

In Table 6 we provide a management algorithm of CCT as a consequence of our systematic review of published cases from the literature including a timeline that might be necessary in severe cases to avoid further complications (nosocomial infections, prolonged TPN and subsequent cholestasis, and MV and ventilator-associated pneumonia). Chemical or surgical pleurodesis and surgical interventions certainly are the last choice of treatment in severe and otherwise untreatable cases of CCT.

\section{Discussion}

As stated in a recent review, interventions include thoracostomy drainage and attempts to decrease chyle flow using a stepwise approach as far as evidence-based treatment choices are still lacking [30] Our systematic review mainly confirmed this management strategy. We found the majority of infants being born premature with a predominance of male gender. The majority of newborns had bilateral effusions. The most common associated congenital anomalies were pulmonary lymphangiectasia and pulmonary hypoplasia, and the most common chromosomal aberrations were Down, Noonan, and Turner syndromes. MV was reported in 381 cases for a mean of 17 days, and pleural punctuations and drainages were performed in 32 and $64 \%$, respectively. Forty-four percent received TPN, $46 \%$ MCT diet, $20 \%$ octreotide, and $3 \%$ somatostatin. Chemical pleurodesis was performed in 116 cases, and surgery was reported in 48 cases with a success rate of $69 \%$. In 462 cases, complete restitution was reported; in 34 of 44 cases, it was reported following intrauterine intervention. Length of hospitalization was a mean of 41 days, and long-term follow-up until 12 years revealed no recurrence of pleural effusions and was in general good including neurodevelopmental follow-up, provided there were no associated anomalies. The mortality rate was $28 \%$.

Prenatal interventions might improve survival in severe cases of fetal chylothorax and usually necessitate referral to an experienced prenatal care center. Interestingly, fetal drainages (pigtail catheter) and subsequent pleurodesis with OK-432 seemed to be promising with a $67 \%$ survival rate. The male to female ratio was found to be 2:1.5, slightly different from the commonly reported ratio of $2: 1$ [30]. The large majority of neonates had bilateral pleural effusions; thus, our data do not support the reports that CCT presents preferably right-sided [30]. Extracting data for optimal management of CCT is difficult. 
Table 6. Management of CCT of the newborn

Prenatal intervention

Prenatal finding of pleural effusions

Associated anomalies; chromosomal aberrations?

Active or palliative treatment

Consider prenatal thoraco-amniotic shunting with a pigtail catheter in an experienced center

Birth

OK-432 instillation for pleurodesis is a more experimental but nevertheless successful approach

Active treatment or palliative care

Respiratory support (MV, CPAP, and HFNC)

Pleural drainage and/or replacement of pigtail catheter

Diagnosis of CCT

Percentage of lymphocytes of pleural fluid $>70 \%$

Lymphocytes $>70 \%$ : high triglyceride levels?

Consider milk feeding to find chylomicrons in the pleural fluid

Document fluid losses to estimate fluid balance and electrolyte and protein (and immune globulins) losses

Week 1-4

Treatment strategies in case of confirmed CCT

Start with total parenteral nutrition (TPN)

Consider removing (if present) the pigtail catheter (and in the same session - using a guide wire - setting a new drainage)

Initiate MCT diet very slowly (dependent on pleural fluids and maintain drainages)

Cave: even some tea might increase pleural fluids

Week 5-6

If pleural fluids increase, back to TPN

MCT diet until full enteral nutrition is reached; thereafter, switch to normal toddler diet

If not possible, consider octreotide treatment by either parenteral or subcutaneous injection/infusion; start with $4 \mu \mathrm{g} / \mathrm{kg} / \mathrm{h}$ up to

$12 \mu \mathrm{g} / \mathrm{kg} / \mathrm{h}$ iv or up to $40 \mu \mathrm{g} / \mathrm{kg} / \mathrm{d}$ s.c

If not successful, consider pleurodesis or surgical ligation of the thoracic duct or both

Prognosis

Consider antibiotics (even prophylactic) and immune globulins every $2-4$ weeks

No infectious complications, no excessive fluid losses: In general, good; no long-term sequelae

Complications, no resolution: serious prognosis; late death possible

MV, mechanical ventilation; CPAP, continuous positive airway pressure; HFNC, high-flow nasal cannulae; CCT, congenital chylothorax; TPN, total parenteral nutrition; MCT, medium chain triglyceride.

Every single case might differ extremely from each other. The first step is confirmation of diagnosis of CCT. In case of uncertainty regarding diagnosis of CCT during TPN and in case of drainages, feeding of small amounts of human milk will lead to the finding of chylomicrones, and the clear fluid of chylus will become creamy or milky. The lymphatic system is responsible for the transport of lipids and the lipophilic vitamins $\mathrm{A}, \mathrm{D}, \mathrm{E}$, and $\mathrm{K}$, and enterocytes transform the lipids to chylomicrons with drainage via the capillary system into the blood circulation. Further functions include fluid and extravasal protein uptake from the interstitial space [5]. High fat intake increases the lymphatic flow dramatically, and long-chain triglycerides will be transported as chylomicrons by the lymphatic system in contrast to medium-and short-chain triglycerides that get metabolized via the portal vein in the liver [5-7]. The chyle is characterized by high triglyceride levels $>1.1 \mathrm{mmol} / \mathrm{L}(>110 \mathrm{mg} / \mathrm{dL})$ and $>1,000$ cells/L with $80-100 \%$ lymphocytes, mainly T lymphocytes $[1,5,8-10$, $159,169]$. Electrolytes, glucose, and protein levels of the chyle are comparable to those of blood plasma; additional chylous components are albumins, globulins, prothrombin, and fibrinogen $[5,20]$.

The first step in the treatment of CCT is respiratory support as far as needed (mainly noninvasive ventilation with continuous positive airway pressure or high flow nasal cannula), pleural fluid drainages, and TPN with nothing per mouth. If CCT resolves, MCT diet might cautiously be initiated until full enteral feeding volumes are reached; thereafter, diet might be switched to human milk (even breastfeeding) or formula diet over several days decreasing the amount of MCT diet steadily. In case of fluid losses over 3 weeks of age, octreotide might be used on a try-and-error basis, starting with $4 \mu \mathrm{g} / \mathrm{kg} / \mathrm{h}$, therafter dou- 
bling the dose if necessary (if there was no treatment effect within $24 \mathrm{~h}$ ) and no higher dose than $12 \mu \mathrm{g} / \mathrm{kg} / \mathrm{h}$. If CCT does not resolve, surgical intervention might be necessary using either ligation of the thoracic duct and/or surgical and/or chemical pleurodesis. Chemical pleurodesis with povidone-iodine was more recently reported [179]. Our own experience in one case was promising regarding nearly complete resolution of CCT, but unfortunately the infants died some days later [179]. From 12 reported cases between 2003 and 2014, the success rate of povidoneiodine pleurodesis was $58 \%$, and the survival rate $75 \%$ [179]. Surgical intervention should be discussed at week 4 and at least be done at the age of 6 weeks. Prophylactic antibiotics can be considered, and immune globulins might be beneficial every 2 weeks in cases of prolonged fluid losses as are coagulation factors. A recent case series of 5 cases with confirmed CCT reported on the necessity of careful management of total body fluid balance and the successful replacement of chylous fluid losses with colloid infusions [192]. Chylous effusions usually last long; however, after 6 weeks, the majority of the effusions (74\%) had ceased according to Buttiker et al. [7]. Late surgical interventions reduced the number of thoracotomies substantially, but led to very long hospitalization times. In contrast, early surgical interventions (after $<3$ weeks), which lead to a higher number of thoracotomies, might reduce the length of stay at the hospital [7]. Others confirm the stepwise procedure in the management of CCT $[4,30]$. Initial treatment consisting of drainage, dietary modifications, and TPN is followed by somatostatin or its preferred analog octreotide [4]. Surgery should be considered for patients who fail these initial steps or in whom complications such as electrolyte and fluid imbalance, malnutrition, or immunodeficiency persist [4].

\section{Conclusion}

We analyzed the largest cohort of cases with CCT from the literature covering 3 decades. First-line treatment remains supportive with stepwise proceeding from respira- tory support, pleural drainages, and nothing per mouth to octreotide and chemical or surgical pleurodesis. Fetal chemical pleurodesis with OK-432 and postnatal chemical pleurodesis with povidone-iodine seem to be promising in life-threatening cases. Otherwise, standard care and treatment did not change markedly during the last years.

\section{Statement of Ethics}

This study protocol was reviewed and the need for approval was waived by the Ethics Committee of the Medical University of Graz (Head Prof. J. Haas, personal communication).

\section{Conflict of Interest Statement}

The authors declare to have no conflicts of interest associated with this study.

\section{Funding Sources}

The authors declare to have had no funding for the study.

\section{Author Contributions}

B.R. was responsible for study design, conceptualization, supervision of data extraction, and wrote the final manuscript. G.S.Y. did all the literature search and data extraction and wrote the tables and the first draft. F.R. supervised the study and edited the manuscript. All the authors approved the final version of the manuscript.

\section{Data Availability Statement}

Raw data are available as online suppl. file.

\section{References}

1 van Straaten HL, Gerards LJ, Krediet TG. Chylothorax in the neonatal period. Eur J Pediatr. 1993;152:2-5.

2 Yinon Y, Kelly E, Ryan G. Fetal pleural effusions. Best Pract Res Clin Obstet Gynaecol. 2008;22:77-96.

3 Merrigan BA, Winter DC, O'Sullivan GC. Chylothorax. Br J Surg. 1997;84(1):15-20.
4 Soto-Martinez M, Massie J. Chylothorax: diagnosis and management in children. Paediatr Respir Rev. 2009;10:199-207.

5 Doerr CH, Miller DL, Ryu JH. Chylothorax. Semin Respir Crit Care Med. 2001;22(06): $617-26$.
6 St-Onge MP, Jones PJ. Physiological effects of medium-chain triglycerides: potential agents in the prevention of obesity. J Nutr. 2002;132: 329-32.

7 Buttiker V, Fanconi S, Burger R. Chylothorax in children: guidelines for diagnosis and management. Chest. 1999;116:682-7. 
8 Cao L, Du Y, Wang L. Fetal pleural effusion and Down syndrome. Intractable Rare Dis Res. 2017;6:158-62.

9 Valentine VG, Raffin TA. The management of chylothorax. Chest. 1992;102:586-91.

10 Agrawal V, Sahn SA. Lipid pleural effusions. Am J Med Sci. 2008;335:16-20.

11 Lopez-Gutierrez JC, Tovar JA. Chylothorax and chylous ascites: management and pitfalls. Semin Pediatr Surg. 2014;23:298-302.

12 Beghetti M, La Scala G, Belli D, Bugmann P, Kalangos A, Le Coultre C. Etiology and management of pediatric chylothorax. J Pediatr. 2000;136:653-8.

13 Cannizzaro V, Frey B, Bernet-Buettiker V. The role of somatostatin in the treatment of persistent chylothorax in children. Eur J Cardiothorac Surg. 2006;30:49-53.

14 Roehr CC, Jung A, Proquitté H, Blankenstein $\mathrm{O}$, Hammer H, Lakhoo K, et al. Somatostatin or octreotide as treatment options for chylothorax in young children: a systematic review. Intensive Care Med. 2006;32:650-7.

15 Buettiker V, Hug MI, Burger R, Baenziger O. Somatostatin: a new therapeutic option for the treatment of chylothorax. Intensive Care Med. 2001;27:1083-6.

16 Wolff AB, Silen ML, Kokoska ER, Rodgers BM. Treatment of refractory chylothorax with externalized pleuroperitoneal shunts in children. Ann Thorac Surg. 1999;68:1053-7.

17 Bernet-Buettiker V, Waldvogel K, Cannizzaro V, Albisetti M. Antithrombin activity in children with chylothorax. Eur J Cardiothorac Surg. 2006;29:406-9.

18 Aubard Y, Derouineau I, Aubard V, Chalifour V, Preux PM. Primary fetal hydrothorax: a literature review and proposed antenatal clinical strategy. Fetal Diagn Ther. 1998;13:32533.

19 Talwar A, Lee HJ. A contemporary review of chylothorax. Indian J Chest Dis Allied Sci. 2008;50:343-51.

20 Graham DD, McGahren ED, Tribble CG, Daniel TM, Rodgers BM. Use of video-assisted thoracic surgery in the treatment of chylothorax. Ann Thorac Surg. 1994;57:1507-2.

21 Nair SK, Petko M, Hayward MP. Aetiology and management of chylothorax in adults. Eur J Cardiothorac Surg. 2007;32:362-9.

22 Huggins JT. Chylothorax and cholesterol pleural effusion. Semin Respir Crit Care Med. 2010;31:743-50.

23 Metzger R, Till H. [Thoracic surgery in neonates and infants with congenital malformations]. Zentralbl Chir. 2009;134:517-23.

24 Lamberts SW, van der Lely AJ, Hofland LJ. New somatostatin analogs: will they fulfil old promises? Eur J Endocrinol. 2002;146:701-5.

25 Suddaby EC, Schiller S. Management of chylothorax in children. Pediatr Nurs. 2004;30: 290-5.

26 Rocha G. Pleural effusions in the neonate. Curr Opin Pulm Med. 2007;13:305-11.

27 Devine PC, Malone FD. Noncardiac thoracic anomalies. Clin Perinatol. 2001;27:865-99.
28 Platis IE, Nwogu CE, Chylothorax. Chylothorax. Thorac Surg Clin. 2006;16(3):209-14

29 Bellini C, Ergaz Z, Boccardo F, Bellini T, Campisi CC, Bonioli E, et al. Dynamics of pleural fluid effusion and chylothorax in the fetus and newborn: role of the lymphatic system. Lymphology. 2013;46:75-84.

30 Attar MA, Donn SM. Congenital chylothorax. Semin Fetal Neonatal Med. 2017;22:234-

31 Hanssler L, Metz KA, Roll C, Hennecke KH. [Primary lymphatic dysplasia in a newborn infant]. Monatsschr Kinderheilkd. 1990;138: $772-4$.

32 Huber A, Schranz D, Merz E. [Congenital chylothorax]. Pneumologie. 1991;45:939-41.

33 Easa D, Balaraman V, Ash K, Thompson B, Boychuk R. Congenital chylothorax and mediastinal neuroblastoma. J Pediatr Surg. 1991; 26:96-8.

34 King PA, Ghosh A, Tang MH, Lam SK. Recurrent congenital chylothorax. Prenat Diagn. 1991;11:809-11.

35 Eddleman KA, Levine AB, Chitkara U, Berkowitz RL. Reliability of pleural fluid lymphocyte counts in the antenatal diagnosis of congenital chylothorax. Obstet Gynecol. 1991;78:530-2.

36 Salem P. A neonate with bilateral refractory chylothorax: a case report. Med J Malaysia. 1991;46:376-8

37 Kolben M, Zimmermann A, Schneider KT. [Acute non-immunologic hydrops fetalis with bilateral chylothorax in the 36th week of pregnancy]. Geburtshilfe Frauenheilkd. 1992; 52:698-701.

38 Hamada H, Fujita K, Kubo T, Iwasaki H. Congenital chylothorax in a trisomy 21 newborn. Arch Gynecol Obstet. 1992;252:55-8.

39 al-Arfaj AL, Upadhyaya P, al-Umran K. Current status of management of neonatal chylothorax. Indian J Pediatr. 1992;59:133-6.

40 Thompson PJ, Greenough A, Brooker R, Nicolaides KH, Gamsu HR. Antenatal diagnosis and outcome in hydrops fetalis. J Perinat Med. 1993;21:63-7.

41 Moerman P, Vandenberghe K, Devlieger $\mathrm{H}$, Van Hole C, Fryns JP, Lauweryns JM. Congenital pulmonary lymphangiectasis with chylothorax: a heterogeneous lymphatic vessel abnormality. Am J Med Genet. 1993;47: 54-8.

42 Chang CA, Teng RJ, Yen SL, Chang S, Ho MM, Hwang KC. Congenital chylothorax managed by partial pleurodesis: report of one case. Zhonghua Min Guo Xiao Er Ke Yi Xue Hui Za Zhi. 1993;34:211-5.

43 Gonen R, Degani S, Shapiro I, Samberg I, Sharf M. The effect of drainage of fetal chylothorax on cardiac and blood vessel hemodynamics. J Clin Ultrasound. 1993;21:265-8.

44 Adiotomre PN, Burns JE, McIntosh N. Hydrops foetalis and chylothorax associated with superior caval vein obstruction and resolution following balloon dilatation. Acta Paediatr. 1994;83:983-5.
45 Geirsson RT, Pàlsson G. Prenatal thoracocentesis may be lifesaving in congenital chylothorax. J Perinat Med. 1994;22:447-8.

46 Hartmann H, Samuels MP, Noyes JP, Goldstraw P, Brookfield DS, Southall DP. A case of congenital chylothorax treated by pleuroperitoneal drainage. J Perinatol. 1994;14:313-5.

47 Thibeault DW, Zalles C, Wickstrom E. Familial pulmonary lymphatic hypoplasia associated with fetal pleural effusions. I Pediatr. 1995; 127:979-83.

48 Mussat P, Dommergues M, Parat S, Mandelbrot L, de Gamarra E, Dumez Y, et al. Congenital chylothorax with hydrops: postnatal care and outcome following antenatal diagnosis. Acta Paediatr. 1995;84:749-55.

49 Watson WJ, Munson DP, Christensen MW Bilateral fetal chylothorax: results of unilateral in utero therapy. Am J Perinatol. 1996;13: 115-7.

50 Shipley CF, 3rd, Simmons CL, Nelson GH. Intrauterine diagnosis of hydrothorax in a fetus who had a combination chylothorax and pulmonary sequestration after delivery. J Perinatol. 1995;15:237-9.

51 Ozkan H, Ay N, Ozaksoy D, Ercal D, Erata Y, Durak $\mathrm{H}$, et al. Congenital chylothorax. Turk J Pediatr. 1996;38:113-7.

52 Yamamoto T, Koeda T, Tamura A, Sawada $\mathrm{H}$ Nagata I, Nagata N, et al. Congenital chylothorax in a patient with 21 trisomy syndrome. Acta Paediatr Jpn. 1996;38:689-91.

53 Murali N, Jana AK, Thomas N, Jeyanthi P. Congenital chylothorax. Indian Pediatr. 1997; 34:644-5.

54 Zenker M, Ries M. Hydrops fetalis caused by chylothorax: an exception to the rule. J Perinat Med. 1997:25:388.

55 Wittman BK, Martin KA, Wilson RD, Peacock D. Complications of long-term drainage of fetal pleural effusion: case report and review of the literature. Am J Perinatol. 1997;14 443-7.

56 Williams MS, Josephson KD. Unusual autosomal recessive lymphatic anomalies in two unrelated Amish families. Am J Med Genet. 1997;73:286-9.

57 Fox GF, Challis D, O’Brien KK, Kelly EN, Ryan G. Congenital chylothorax in siblings. Acta Paediatr. 1998;87:1010-2.

58 Dutheil P, Leraillez J, Guillemette J, Wallach D. Generalized lymphangiomatosis with chylothorax and skin lymphangiomas in a neonate. Pediatr Dermatol. 1998;15:296-8

59 Ibrahim H, Asamoah A, Krouskop RW, Lewis D, Webster P, Pramanik AK. Congenital chylothorax in neonatal thyrotoxicosis. J Perinatol. 1999;19:68-71.

60 Gonen R, Degani S, Kugelman A, Abend M, Bader D. Intrapartum drainage of fetal pleural effusion. Prenat Diagn. 1999;19:1124-6.

61 Takeuchi K, Moriyama T, Oomori S, Masuko K, Maruo T. Management of acute chylothorax with hydrops fetalis diagnosed in the third trimester of pregnancy. Fetal Diagn Ther. $1999 ; 14: 264-5$ 
62 Fernandez Alvarez JR, Kalache KD, Grauel EL. Management of spontaneous congenital chylothorax: oral medium-chain triglycerides versus total parenteral nutrition. Am J Perinatol. 1999;16:415-20.

63 Engum SA, Rescorla FJ, West KW, Scherer LR 3rd, Grosfeld JL. The use of pleuroperitoneal shunts in the management of persistent chylothorax in infants. J Pediatr Surg. 1999;34: 286-90.

64 Puddy V, Lam BC, Tang M, Wong KY, Lam $\mathrm{YH}$, Wong $\mathrm{K}$, et al. Variable levels of mosaicism for trisomy 21 in a non-immune hydropic infant with chylothorax. Prenat Diagn. 1999;19:764-6.

65 Battin MR, Yan J, Aftimos S, Roberts A. Congenital chylothorax in siblings. BJOG. 2000; 107:1516-8.

66 Koksal N, Demir S, Okan M, Gebitekin C, Senkaya I. Congenital chylothorax. Turk J Med Sci. 2000;30:307-9.

67 Dubin PJ, King IN, Gallagher PG. Congenital chylothorax. Curr Opin Pediatr. 2000;12: 505-9.

68 Al-Tawil K, Ahmed G, Al-Hathal M, Al-Jarallah Y, Campbell N. Congenital chylothorax. Am J Perinatol. 2000;17(3):121-6.

69 Grisaru-Granovsky S, Seaward PG, Windrim R, Wyatt P, Kelly EN, Ryan G. Mid-trimester thoracoamniotic shunting for the treatment of fetal primary pleural effusions in a twin pregnancy. a case report. Fetal Diagn Ther. 2000;15:209-11.

70 Kugelman A, Gonen R, Bader D. Potential role of high-frequency ventilation in the treatment of severe congenital pleural effusion. Pediatr Pulmonol. 2000;29:404-8.

71 Koike T, Minakami H, Kosuge S, Izumi A, Shiraishi H, Sato I. Severe hypoproteinemia in a fetus after pleuro-amniotic shunts with double-basket catheters for treatment of chylothorax. J Obstet Gynaecol Res. 2000;26:373-6.

72 Chen CP, Chang TY, Wang W. Resolution of fetal bilateral chylothorax and ascites after two unilateral thoracocenteses. Ultrasound Obstet Gynecol. 2001;18:401-2.

73 Tanemura M, Nishikawa N, Kojima K, Suzuki Y, Suzumori K. A case of successful fetal therapy for congenital chylothorax by intrapleural injection of OK-432. Ultrasound $\mathrm{Ob}$ stet Gynecol. 2001;18:371-5.

74 Okawa T, Takano Y, Fujimori K, Yanagida K, Sato A. A new fetal therapy for chylothorax: pleurodesis with OK-432. Ultrasound Obstet Gynecol. 2001;18:376-7.

75 Turan O, Canter B, Ergenekon E, Koç E, Atalay $\mathrm{Y}$. Chylothorax and respiratory distress in a newborn with trisomy 21. Eur J Pediatr. 2001;160:744-5.

76 Cardoso D, Tuna M, Abrantes M, dos Santos HG, Da Silva LJ. Congenital chylothorax associated with trisomy X. Eur J Pediatr. 2001; 160:743.

77 Bartha JL, Comino-Delgado R. Fetal chylothorax response to maternal dietary treatment. Obstet Gynecol. 2001;97:820-3.
78 Prasad R, Singh K, Singh R. Bilateral congenital chylothorax with Noonan syndrome. Indian Pediatr. 2002;39:975-6.

79 Resch B, Popper HH, Urlesberger B, Müller WD. Pulmonary eosinophilic vasculitis in a neonate with congenital chylothorax. Pediatr Pulmonol. 2002;33:501-4.

80 Parra J, Amenedo M, Muñiz-Díaz E, Ormo F Simó M, Vega C, et al. A new successful therapy for fetal chylothorax by intrapleural injection of maternal blood. Ultrasound Obstet Gynecol. 2003;22:290-4.

81 Orange JS, Geha RS, Bonilla FA. Acute chylothorax in children: selective retention of memory T cells and natural killer cells. J Pediatr. 2003;143:243-9.

82 Brito T, Oliveira C, Sousa L, Barbosa A, Pinho $\mathrm{O}$, Mesquita M, et al. Congenital chylothorax: a case report. Ultrasound Obstet Gynecol. 2003;21:70-1.

83 Brissaud O, Desfrere L, Mohsen R, Fayon M, Demarquez JL. Congenital idiopathic chylothorax in neonates: chemical pleurodesis with povidone-iodine (Betadine). Arch Dis Child Fetal Neonatal Ed. 2003;88:F531-3.

84 Bellini C, Mazzella M, Arioni C, Campisi C, Taddei G, Tomà $P$, et al. Hennekam syndrome presenting as nonimmune hydrops fetalis, congenital chylothorax, and congenital pulmonary lymphangiectasia. Am J Med Genet A. 2003;120A:92-6.

85 Carvalho DR, Alves VV, Minaré-Júnior A, Peres LC, Pina-Neto JM, Ramos ES. Noonan syndrome associated with unilateral iris coloboma and congenital chylothorax in an infant. Clin Dysmorphol. 2003;12:143-4.

86 Goto M, Kawamata K, Kitano M, Watanabe $\mathrm{K}$, Chiba Y. Treatment of chylothorax in a premature infant using somatostatin. J Perinatol. 2003;23:563-4.

87 Jorgensen C, Brocks V, Bang J, Jorgensen FS, Rønsbro L. Treatment of severe fetal chylothorax associated with pronounced hydrops with intrapleural injection of OK-432. Ultrasound Obstet Gynecol. 2003;21:66-9.

88 Miera O, Mildenberger E, van Baalen A, Fuhr N. [Neonatal chylothorax with trisomy 21]. Z Geburtshilfe Neonatol. 2004;208:29-31.

89 Picone O, Benachi A, Mandelbrot L, Ruano R, Dumez Y, Dommergues M. Thoracoamniotic shunting for fetal pleural effusions with hydrops. Am J Obstet Gynecol. 2004;191:204750.

90 Wasmuth-Pietzuch A, Hansmann M, Bartmann P, Heep A. Congenital chylothorax: lymphopenia and high risk of neonatal infections. Acta Paediatr. 2004;93:220-4.

91 Bellini C, Mazzella M, Campisi C, Taddei G, Mosca F, Tomà $\mathrm{P}$, et al. Multimodal imaging in the congenital pulmonary lymphangiectasia-congenital chylothorax-hydrops fetalis continuum. Lymphology. 2004;37:22-30.

92 Rasiah SV, Oei J, Lui K. Octreotide in the treatment of congenital chylothorax. J Paediatr Child Health. 2004;40:585-8.
93 Coulter DM. Successful treatment with octreotide of spontaneous chylothorax in a premature infant. J Perinatol. 2004;24:1945.

94 Sivasli E, Dogru D, Aslan AT, Yurdakok M, Tekinalp G. Spontaneous neonatal chylothorax treated with octreotide in Turkey: a case report. J Perinatol. 2004;24:261-2.

95 Tsukihara A, Tanemura M, Suzuki Y, Sato T, Tanaka T, Suzumori K. Reduction of pleural effusion by OK-432 in a fetus complicated with congenital hydrothorax. Fetal Diagn Ther. 2004;19:327-31.

96 Young S, Dalgleish S, Eccleston A, Akierman A, McMillan D. Severe congenital chylothorax treated with octreotide. J Perinatol. 2004; 24:200-2.

97 Chen M, Chen CP, Shih JC, Chou HC, Yu CL, Wang BT, et al. Antenatal treatment of chylothorax and cystic hygroma with OK432 in nonimmune hydrops fetalis. Fetal Diagn Ther. 2005;20:309-15.

98 Lee CY, Jan SL, Wang TM, Chi CS. Congenital chylothorax associated with isolated congenital hypoplastic superior caval vein: a case report. Acta Paediatr. 2005;94:1840-3.

99 Chang YL, Lien R, Wang CJ, Chang SD, Soong YK. Congenital chylothorax in three siblings. Am J Obstet Gynecol. 2005;192: 2065-6.

100 Chen M, Shih JC, Wang BT, Chen CP, Yu CL. Fetal OK-432 pleurodesis: complete or incomplete? Ultrasound Obstet Gynecol. 2005;26:791-3.

101 Sahin Y, Aydin D. Congenital chylothorax treated with octreotide. Indian J Pediatr. 2005;72:885-8.

102 Dempsey EM, Sant'Anna GM, Williams RL, Brouillette RT. Congenital pulmonary lymphangiectasia presenting as nonimmune fetal hydrops and severe respiratory distress at birth: not uniformly fatal. Pediatr Pulmonol. 2005; $40: 270-4$.

103 Genevieve D, Walter E, Gorry P, Jacquemont ML, Dupic L, Layet V, et al. Gorlin syndrome presenting as prenatal chylothorax in a girl. Prenat Diagn. 2005;25:997-9.

104 Chen CP. Fetal therapy and cytogenetic testing: prenatal detection of chromosome aberration during thoracocentesis for congenital chylothorax by karyotyping from pleural effusion fluid and review of the literature. Genet Couns. 2005;16:301-5.

105 Smith RP, Illanes S, Denbow ML, Soothill PW. Outcome of fetal pleural effusions treated by thoracoamniotic shunting. Ultrasound Obstet Gynecol. 2005;26:63-6.

106 Maayan-Metzger A, Sack J, Mazkereth R, Vardi A, Kuint J. Somatostatin treatment of congenital chylothorax may induce transient hypothyroidism in newborns. Acta Paediatr. 2005;94:785-9.

107 Siu SL, Lam DS. Spontaneous neonatal chylothorax treated with octreotide. J Paediatr Child Health. 2006;42:65-7. 
108 Romer S, Opgen-Rhein B, Chaoui R, Scheer I, Czernik C, Obladen M. Bilateral agenesis of the superior vena cava associated with congenital hydrothorax. Ultrasound Obstet Gynecol. 2006;28:842-4.

109 Funke S, Kellermayer R, Czakó M, So J, Kosztolányi G, Ertl T. Congenital chylothorax in Opitz G/BBB syndrome. Am J Med Genet A. 2006;140:1119-21.

110 D'Amelio R, Rauccio V, Melluso J, Dettori C, Grande S, Feraudo E, et al. Non-immune foetal hydrops: a case report. Clin Exp Obstet Gynecol. 2006;33:241-3.

111 Stevenson DA, Pysher TJ, Ward RM, Carey JC. Familial congenital non-immune hydrops, chylothorax, and pulmonary lymphangiectasia. Am J Med Genet A. 2006;140: 368-72.

112 Rocha G, Fernandes P, Rocha P, Quintas C, Martins T, Proença E. Pleural effusions in the neonate. Acta Paediatr. 2006;95:791-8.

113 Tsukimori K, Nakanami N, Fukushima K, Yoshimura T, Hikino S, Nakano H. Pleural fluid/serum immunoglobulin ratio is a diagnostic marker for congenital chylothorax in utero. J Perinat Med. 2006;34:313-7.

114 Cannizzaro V, Frey B, Bernet-Buettiker V. The role of somatostatin in the treatment of persistent chylothorax in children. Eur J Cardiothorac Surg. 2006;30:49-53.

115 Gaede C. Congenital chylothorax: a case study. Neonatal Netw. 2006;25:371-81.

116 Akcakus M, Koklu E, Bilgin M, Kurtoglu S, Altunay L, Canpolat M, et al. Congenital pulmonary lymphangiectasia in a newborn: a response to autologous blood therapy. Neonatology. 2007;91:256-9.

117 Wilson RD, Pawel B, Bebbington M, Johnson MP, Lim FY, Stamilio D, et al. Congenital pulmonary lymphangiectasis sequence: a rare, heterogeneous, and lethal etiology for prenatal pleural effusion. Prenat Diagn. 2006;26:1058-61.

118 Chen C, Wang T, Chern S, Tzen C, Hsu C, Lee $C$, et al. Prenatal diagnosis of congenital chylothorax associated with de novopartial trisomy $12 \mathrm{q}(12 \mathrm{q} 21.2 \rightarrow \mathrm{qter})$. Prenat Diagn. 2006;26:752-5.

119 Mitanchez D, Walter-Nicolet E, Salomon R, Bavoux F, Hubert P. Congenital chylothorax: what is the best strategy? Arch Dis Child Fetal Neonatal Ed. 2006;91:F153-4.

120 Kallanagowdar C, Craver RD. Neonatal pleural effusion. Spontaneous chylothorax in a newborn with trisomy 21. Arch Pathol Lab Med. 2006;130:e22-3.

121 Paget-Brown A, Kattwinkel J, Rodgers BM, Michalsky MP. The use of octreotide to treat congenital chylothorax. J Pediatr Surg. 2006; 41:845-7.

122 de Bruijn D, van Oort A, Kapusta L. Ebstein's anomaly with severe hypoplastic and stenotic pulmonary venous connections: an unusual cause of congenital chylothorax. U1trasound Obstet Gynecol. 2007;30:910-2.
123 Yamamoto M, Insunza A, Carrillo J, Caicedo LA, Paiva E, Ville Y. Intrathoracic pressure in congenital chylothorax: keystone for the rationale of thoracoamniotic shunting? Fetal Diagn Ther. 2007;22:169-71.

124 Abrams ME, Meredith KS, Kinnard P, Clark RH. Hydrops fetalis: a retrospective review of cases reported to a large national database and identification of risk factors associated with death. Pediatrics. 2007;120:84-9.

125 Nygaard U, Sundberg K, Nielsen HS, Hertel $\mathrm{S}$, Jørgensen C. New treatment of early fetal chylothorax. Obstet Gynecol. 2007;109: 1088-92.

126 Chen M, Hsieh CY, Shih JC, Chou CH, Ma GC, Chen TH, et al. Proinflammatory macrophage migratory inhibition factor and interleukin-6 are concentrated in pleural effusion of human fetuses with prenatal chylothorax. Prenat Diagn. 2007;27:435-41.

127 Altuncu E, Akman I, Kiyan G, Ersu R, Yurdakul Z, Bilgen $\mathrm{H}$, et al. Report of three cases: congenital chylothorax and treatment modalities. Turk J Pediatr. 2007;49:418-21.

128 Chan GM, Lechtenberg E. The use of fat-free human milk in infants with chylous pleural effusion. J Perinatol. 2007;27:434-6.

129 Murabayashi N, Sugiyama T, Kusaka H, Sagawa N. Thoracoamniotic shunting with double-basket catheters for fetal chylothorax in the second trimester. Fetal Diagn Ther. 2007;22:425-7.

130 Bellini C, Boccardo F, Campisi C, Villa G, Taddei G, Traggiai C, et al. Lymphatic dysplasias in newborns and children: the role of lymphoscintigraphy. J Pediatr. 2008; 152: 587-3.

131 Smets K. X-linked myotubular myopathy and chylothorax. Neuromuscul Disord. 2008;18:183-4.

132 Ma GC, Liu CS, Chang SP, Yeh KT, Ke YY, Chen $\mathrm{TH}$, et al. A recurrent ITGA9 missense mutation in human fetuses with severe chylothorax: possible correlation with poor response to fetal therapy. Prenat Diagn. 2008; 28:1057-63.

133 Siddiqui MMF, Crabbe DCG. Octreotide and congenital chylothorax. Case report and review of the literature. J Pediatr Surg Specialties. 2008;2:46-50.

134 Diomande D, Husseini K, Meau-Petit V, Dupont C, Picone O, Boileau P. Early-onset pneumothorax indicates poor outcome in newborns with congenital idiopathic chylothorax. Arch Dis Child Fetal Neonatal Ed. 2008;93:F327-8.

135 Lim RK, Malik SA. Recurrent pleural effusions in a neonate. Pediatr Emerg Care. 2008;24:41-3.

136 Lahmiti S, Elhoudzi J, Aboussad A. Congenital Chylothorax. ScientificWorldJournal. 2009;9:431-4.

137 Ergaz Z, Bar-Oz B, Yatsiv I, Arad I. Congenital chylothorax: clinical course and prognostic significance. Pediatr Pulmonol. 2009; 44:806-11.
138 Bulbul A, Okan F, Nuhoglu A. Idiopathic congenital chylothorax presented with severe hydrops and treated with octreotide in term newborn. J Matern Fetal Neonatal Med. 2009;22:1197-200.

139 Mathur NB, Singh B, Kumar A, Aggarwal SK. Successful treatment of congenital chylothorax using fibrin glue. Indian J Pediatr. 2009;76:758.

140 Matsukuma E, Aoki Y, Sakai M, Kawamoto $\mathrm{N}$, Watanabe $\mathrm{H}$, Iwagaki $\mathrm{S}$, et al. Treatment with OK-432 for persistent congenital chylothorax in newborn infants resistant to octreotide. J Pediatr Surg. 2009;44:e37-9.

141 Chen $\mathrm{CH}$, Chen TH, Kuo SJ, Chen CP, Lee DJ, Ke YY, et al. Genetic evaluation and management of fetal chylothorax: review and insights from a case of Noonan syndrome. Lymphology. 2009;42:134-8.

142 Cleveland K, Zook D, Harvey K, Woods RK. Massive chylothorax in small babies. J Pediatr Surg. 2009;44:546-50.

143 Arafa A, Peitsidis P, Kadir RA. Unusual case of congenital chylothorax. J Obstet Gynaecol. 2009;29:59-60.

144 Waterfield T, Lakhoo K. Challenges in the management of refractory bilateral idiopathic congenital chylothoraces in a newborn. Eur J Pediatr Surg. 2010;20:198-201.

145 Amoozgar H, Mehdizadegan N, Ajami G, Borzouee M. Chylothorax in children, A retrospective study. J Pediatric Sci. 2010;2:e14.

146 Murki S, Faheemuddin M, Gaddam P. Congenital chylothorax--successful management with chemical pleurodesis. Indian J Pediatr. 2010;77:332-4.

147 Caserio S, Gallego C, Martin P, Moral MT, Pallas CR, Galindo A. Congenital chylothorax: from foetal life to adolescence. Acta Paediatr. 2010;99:1571-7.

148 Sousa PR, Leitao H, Camacho MC, Nunes JL. Idiopathic congenital chylothorax treated with octreotide. BMJ Case Rep. 2010 May 19;2010.

149 Le Nue R, Molinaro F, Gomes-Ferreira C, Scheib-Brolly C, Escande B, Kuhn P, et al Surgical management of congenital chylothorax in children. Eur J Pediatr Surg. 2010; 20:307-11.

150 Shih YT, Su PH, Chen JY, Lee IC, Hu JM, Chang HP. Common etiologies of neonatal pleural effusion. Pediatr Neonatol. 2011;52: 251-5.

151 Foo NH, Hwang YS, Lin CC, Tsai WH. Congenital chylothorax in a late preterm infant and successful treatment with octreotide. Pediatr Neonatol. 2011;52:297-301.

152 Consigli C, Tempera A, Alegiani C, Spinelli M, Scapillati E, Haass C, et al. Ventilation mode and outcome of premature infants with congenital chylothorax. J Matern Fetal Neonatal Med. 2012;25:1627-30.

153 Mele P, Sridhar S. Congenital pulmonary lymphangiectasia: an unusual presentation of nonimmune hydrops in a preterm infant. Adv Neonatal Care. 2012;12:166-71. 
154 Kaneko M, Kanai Y, Go H, Imamura T, Momoi N, Hosoya M. Five cases of congenital chylothorax treated by intrapleural minocycline. AJP Rep. 2012;2:25-8.

155 Yang YS, Ma GC, Shih JC, Chen CP, Chou $\mathrm{CH}$, Yeh KT, et al. Experimental treatment of bilateral fetal chylothorax using in-utero pleurodesis. Ultrasound Obstet Gynecol. 2012;39:56-62.

156 Leung VK, Suen SS, Ting YH, Law LW, Lau TK, Leung TY. Intrapleural injection of OK432 as the primary in-utero treatment for fetal chylothorax. Hong Kong Med J. 2012;18: 156-9.

157 Horvers M, Mooij CF, Antonius TA. Is octreotide treatment useful in patients with congenital chylothorax? Neonatology. 2012; 101:225-31.

158 Resch B, Halmer M, Müller WD, Eber E. Long-term follow-up of children with congenital chylothorax. Eur Respir J. 2012;40: 1060-2.

159 Bellini C, Ergaz Z, Radicioni M, Forner-Cordero I, Witte M, Perotti G, et al. Congenital fetal and neonatal visceral chylous effusions: neonatal chylothorax and chylous ascites revisited. A multicenter retrospective study. Lymphology. 2012;45:91-102.

160 Shah D, Sinn JK. Octreotide as therapeutic option for congenital idiopathic chylothorax: a case series. Acta Paediatr. 2012;101: e151-5.

161 Oh JH, Lee G, Lee JH. Congenital chylothorax and pulmonary hypertension complicated with heart failure and hepatopathy. Pediatr Int. 2013;55:e7-10.

162 Choo YM, Lim CT. Treatment of congenital chylothorax with octreotide in a hydropic preterm infant. Paediatr Int Child Health. 2013;33:116-9.

163 Lomauri K. Congenital chylothorax in newborn with trisomy 21. Georgian Med News. 2014;236:74-7.

164 Downie L, Sasi A, Malhotra A. Congenital chylothorax: associations and neonatal outcomes. J Paediatr Child Health. 2014;50: 234-8.

165 Wang LS, Wang HY, Zhou WH. Mid-term follow-up of neonatal pleural effusion. Indian Pediatr. 2014;51:487-9.

166 Cremonini G, Poggi A, Capucci R, Vesce F, Patella A, Marci R. Rare case of massive congenital bilateral chylothorax in a hydropic fetus with true mosaicism 47,XXX/46,XX. J Obstet Gynaecol Res. 2014;40:259-62.
167 Gupta V, Mahendri NV, Tete P, Santhanam S. Skimmed milk preparation in management of congenital chylothorax. Indian Pediatr. 2014;51:146-8.

168 Derderian SC, Trivedi S, Farrell J, Keller RL, Rand L, Goldstein R, et al. Outcomes of fetal intervention for primary hydrothorax. $\mathrm{JPe}-$ diatr Surg. 2014;49:900-4; discussion 903-4.

169 Bengtsson BO. Outcome of neonatal chylous effusions: what do you tell the parents? A 10-year experience in a community hospital. Am J Perinatol. 2014;31:1037-42.

170 Shibasaki J, Hara H, Mihara M, Adachi S, Uchida Y, Itani Y. Evaluation of lymphatic dysplasia in patients with congenital pleural effusion and ascites using indocyanine green lymphography. J Pediatr. 2014;164:1116-e1.

171 Nowakowska D, Gaj Z, Grzesiak M, Gulczyńska E, Wilczyński J. Successful treatment of fetal bilateral primary chylothorax: report of the two cases. Ginekol Pol. 2014;85: 708-12.

172 Utture A, Kodur V, Mondkar J. Chemical pleurodesis with oxytetracycline in congenital chylothorax. Indian Pediatr. 2016;53: 1105-6.

173 Bialkowski A, Poets CF, Franz AR. Erhebungseinheit fur seltene padiatrische $\mathrm{Er}$ krankungen in Deutschland Study Group. Congenital chylothorax: a prospective nationwide epidemiological study in Germany. Arch Dis Child Fetal Neonatal Ed. 2015;100: F169-72.

174 Afsharpaiman S, Rezaee Zavareh MS, Torkaman M. Low dose of octreotide can be helpful in the management of congenital chylothorax. Iran Red Crescent Med J. 2015;17: e18915.

175 Clark ME, Woo RK, Johnson SM. Thoracoscopic pleural clipping for the management of congenital chylothorax. Pediatr Surg Int. 2015;31:1133-7.

176 Malleske DT, Yoder BA. Congenital chylothorax treated with oral sildenafil: a case report and review of the literature. J Perinatol. 2015;35:384-6.

177 Cakir U, Kahvecioglu D, Yildiz D, Alan S, Erdeve O, Atasay B, et al. Report of a case of neonatal chylothorax that responded to long-term octreotide treatment, and review of the literature. Turk J Pediatr. 2015;57: 195-7.

178 Slater BJ, Rothenberg SS. Thoracoscopic thoracic duct ligation for congenital and acquired disease. J Laparoendosc Adv Surg Tech A. 2015;25:605-7.
179 Resch B, Freidl T, Reiterer F. Povidone-iodine pleurodesis for congenital chylothorax of the newborn. Arch Dis Child Fetal Neonatal Ed. 2016;101:F87-8.

180 Lee CJ, Tsao PN, Chen CY, Hsieh WS, Liou JY, Chou HC. Prenatal therapy improves the survival of premature infants with congenital chylothorax. Pediatr Neonatol. 2016;57: 127-32.

181 Brock WW, Bradshaw WT. Congenital chylothorax: a unique presentation of nonimmune hydrops fetalis in a preterm infant. Adv Neonatal Care. 2016;16:114-23.

182 Yin R, Zhang R, Wang J, Yuan L, Hu L, Jiang $\mathrm{S}$, et al. Effects of somatostatin/octreotide treatment in neonates with congenital chylothorax. Medicine. 2017;96:e7594.

183 Church JT, Antunez AG, Dean A, Matusko N, Deatrick KB, Attar MA, et al. Evidencebased management of chylothorax in infants. J Pediatr Surg. 2017;52:907-12.

184 Peng YF, Zhong W, He QM, Wang Z, Yu JK Zhang GL, et al. Treatment of fetal congenital chylothorax: report of eight cases at a mainland Chinese medical center. Taiwan J Obstet Gynecol. 2017;56:867-9.

185 Shillitoe BMJ, Berrington J, Athiraman N. Congenital pleural effusions: 15 years singlecentre experience from North-East England. J Matern Fetal Neonatal Med. 2018;31 2086-9.

186 Carr BD, Sampang L, Church JT, Mon RA, Gadepalli SK, Attar MA, et al. Fetal intervention for congenital chylothorax is associated with improved outcomes in early life. J Surg Res. 2018;231:361-5.

187 Sahoo T, Mangla MK, Sethi A, Thukral A. Successful treatment of congenital chylothorax with skimmed milk and long course octreotide. BMJ Case Rep. 2018;11.

188 Pisek G. Report of a case of chylothorax. Arch Pediatr. 1917;34:929-32.

189 Stewart C, Linner H. Chylothorax in the newborn infant: a report of a case. Am J Dis Child. 1926;31:654-6.

190 Defoort P, Thiery M. Antenatal diagnosis of congenital chylothorax by gray scale sonography. J Clin Ultrasound. 1928;6:47-8.

191 Faul JL, Berry GJ, Colby TV, Ruoss SJ, Walter MB, Rosen GD, et al. Thoracic lymphangiomas, lymphangiectasis, lymphangiomatosis, and lymphatic dysplasia syndrome. Am J Respir Crit Care Med. 2000;161:103746.

192 Healy H, Gipson K, Hay S, Bates S, Kinane TB. Management and outcomes of congenital chylothorax in the neonatal intensive care unit: a case series. Pediatr Investig. 2017;1: 21-5. 